Uldaho Law

Digital Commons @ Uldaho Law

2020

\title{
The Historical Evolution of the Methodology for Quantifying Federal Reserved Instream Water Rights for American Indian Tribes
}

Dylan R. Hedden-Nicely

University of Idaho, College of Law, dhedden@uidaho.edu

Follow this and additional works at: https://digitalcommons.law.uidaho.edu/faculty_scholarship

Part of the Indigenous, Indian, and Aboriginal Law Commons, and the Water Law Commons

\section{Recommended Citation}

50 Envtl. L. 205 (2020)

This Article is brought to you for free and open access by the Faculty Works at Digital Commons @ Uldaho Law. It has been accepted for inclusion in Articles by an authorized administrator of Digital Commons @ Uldaho Law. For more information, please contact annablaine@uidaho.edu. 


\section{HEINONLINE}

DATE DOWNLOADED: Mon Sep 20 18:08:01 2021

SOURCE: Content Downloaded from HeinOnline

Citations:

Bluebook 21st ed.

Dylan R. Hedden-Nicely, The Contemporary Methodology for Quantifying Reserved Instream Flow Water Rights to Support Aquatic Habitat, 50 ENVTL. L. 257 (2020).

ALWD 6th ed.

Hedden-Nicely, D. R., The contemporary methodology for quantifying reserved instream flow water rights to support aquatic habitat, 50(1) Envtl. L. 257 (2020).

APA 7th ed.

Hedden-Nicely, D. R. (2020). The contemporary methodology for quantifying reserved instream flow water rights to support aquatic habitat. Environmental Law, 50(1), 257-286.

Chicago 17th ed.

Dylan R. Hedden-Nicely, "The Contemporary Methodology for Quantifying Reserved Instream Flow Water Rights to Support Aquatic Habitat," Environmental Law 50, no. 1 (Winter 2020): 257-286

McGill Guide 9th ed.

Dylan R Hedden-Nicely, "The Contemporary Methodology for Quantifying Reserved Instream Flow Water Rights to Support Aquatic Habitat" (2020) 50:1 Envtl L 257.

AGLC 4th ed.

Dylan R Hedden-Nicely, 'The Contemporary Methodology for Quantifying Reserved Instream Flow Water Rights to Support Aquatic Habitat' (2020) 50(1) Environmental Law 257.

MLA 8th ed.

Hedden-Nicely, Dylan R. "The Contemporary Methodology for Quantifying Reserved Instream Flow Water Rights to Support Aquatic Habitat." Environmental Law, vol. 50, no. 1 , Winter 2020, p. 257-286. HeinOnline.

OSCOLA 4th ed.

Dylan R Hedden-Nicely, 'The Contemporary Methodology for Quantifying Reserved Instream Flow Water Rights to Support Aquatic Habitat' (2020) 50 Envtl L 257

Provided by:

University of Idaho Law Library

-- Your use of this HeinOnline PDF indicates your acceptance of HeinOnline's Terms and Conditions of the license agreement available at

https://heinonline.org/HOL/License

-- The search text of this PDF is generated from uncorrected OCR text.

-- To obtain permission to use this article beyond the scope of your license, please use: 


\title{
THE CONTEMPORARY METHODOLOGY FOR QUANTIFYING RESERVED INSTREAM FLOW WATER RIGHTS TO SUPPORT AQUATIC HABITAT
}

\author{
BY \\ DYLAN R. HEDDEN-NICELY*
}

\begin{abstract}
Since time immemorial, indigenous people have relied on the streams of their territory for food, fiber, transportation, recreation, cultural, and spiritual needs. Accordingly, tribal peopleparticularly those in the region now called the Northwestern United States-placed singular emphasis on preserving their traditional subsistence culture when negotiating with the United States during the reservation era. Although rarely expressed in these treaties, the tribes are nonetheless entitled to water rights sufficient to fulfill these traditional subsistence treaty rights. Of the suite of water rights to maintain traditional uses of water, likely the most commonly claimed is for water to maintain fish habitat. A companion article in this same issue explores the evolution of the methodology for quantifying these water rights, which has slowly converged on the Instream Flow Incremental Methodology (IFIM) and its component part, the Physical Habitat Simulation Model (PHABSIM) methodology. The purpose of this Article is to provide an explanation of the current IFIM/PHABSIM methodology to put
\end{abstract}

"Dylan R. Hedden-Nicely is a citizen of the Cherokee Nation of Oklahoma. He is an Associate Professor of Law at the University of Idaho (UI) College of Law and Director of the UI Native American Law Program. Professor Hedden-Nicely is also affiliate faculty for the UI's American Indian Studies Program, Water Resources Program, and Core Faculty for UT's Environmental Science Program. The author would like to recognize the work of Jennifer Tengono, Dakota Goodman, and Matthew Ryan for their help in researching and editing this Article. Professor Hedden-Nicely can be reached at dhedden@uidaho.edu. All filings cited herein are available at: https://digitalcommons.law.uidaho.edu/hedden-nicely/.

The author acknowledges that he lives and makes his living in the aboriginal homeland of the Nimi'ipuu (Nez Perce) and Schitsu'umsh (Coeur d'Alene) peoples and that the University of Idaho is situated within the boundaries of the Nez Perce Tribe's unceded 1855 Reservation. These Tribal Nations are distinct, sovereign, legal and political entities with their own powers of self-governance and self-determination. Honor the treaties; "[g]reat nations, like great men, should keep their word." F.P.C. v. Tuscarora Indian Nation, 362 U.S. 99, 142 (1960) (Black, J., dissenting). 
practitioners in the position to understand and meaningfully apply the method.

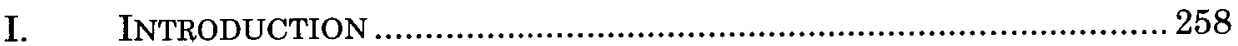

II. DEFINING THE QUANTIFICATION STANDARD ............................... 260

III. THE CONTEMPORARY METHOD: THE COMBINED INSTREAM FLOW INCREMENTAL METHOD (IFIM) AND PHYSICAL HABITAT SIMULATION (PHABSIM) METHODOLOGY

A. Preliminary Matters: Selection of Claim Reaches, Identification and Prioritization of Target Species, and Identification of Species Distribution Periodicity ................. 265

B. Data Collection Methodology ............................................... 268

C. Determination of the Weighted Usable Area: Hydraulic Modeling and Habitat Suitability Curves............................ 274

D. Capping the Claims: Marrying the Hydraulics and Habitat Suitability to the Hydrology .................................... 281

E. Tying it Together: The Four Steps Applied .......................... 282

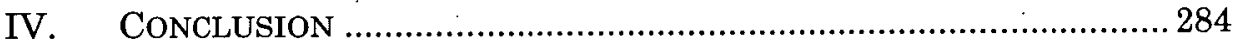

"Lawyers don't do math."

\section{INTRODUCTION}

I have always found the common refrain that "lawyers don't do math" to be curious. Perhaps this is due to my background; I became a lawyer precisely because it provided the opportunity for me to blend my passion for both law and science. Given that, I recognize that my road is not the common path. Nonetheless, I am constantly surprised at the lengths many of my students and colleagues have gone in a futile effort to avoid science, engineering, and-most dreaded of all-math. These poor souls graduate from their post-secondary education having actively avoided these subjects only to fall into a practice that they only later realize involves $a$ lot of math and science. The idle ones among us rely heavily on technical experts to shore up their lack of understanding or, worse yet, their unwillingness to understand. Most lawyers I have met, however, are committed to their clients and their craft such that they spend their career educating themselves on the scientific principles underpinning their particular area of the law so they can be active partners with the necessary technical experts in a joint effort to best situate their clients. Even those of us that do have a technical background are constantly learning new scientific principles and methodologies. This Article is designed to help these latter groups of lawyers by providing information related to commonly used technical methodologies in the law. In this case, we discuss the method for estimating the flow necessary to protect instream habitat to support 
fish: the Instream Flow Incremental Methodology (IFIM) and its component part, the Physical Habitat Simulation Model (PHABSIM).

This Article is situated in the context of furthering reserved water rights that are claimed by American Indian tribes in order to protect aquatic habitat. Since time immemorial, indigenous peopleparticularly those in the region now referred to as the Northwestern part of the United States-have relied on the streams of their territory for food, fiber, transportation, recreation, cultural, and spiritual needs. ${ }^{1}$ As a result of that interdependence, one objective for tribal people when they negotiated with the United States during the reservation era was to preserve their traditional way of life, along with the water rights sufficient to fulfill those important purposes. ${ }^{2}$

However, this begs the question of how much water is necessary to fulfill these important traditional purposes. Unlike reserved water rights for irrigation -which has the well settled practicably irrigable acreage (PIA) standard-the United States Supreme Court has not identified a single quantification methodology appropriate for traditional uses of water. Instead, lower courts have fashioned a more ad hoc approach to quantifying traditional reserved water rights. ${ }^{3}$ This seems preferable given that unlike irrigation water rights, which are fairly uniform in their nature, each tribe's traditional uses of water are unique and driven by the physical, historical, and cultural factors present for each tribe. Of the suite of water rights to maintain traditional uses of water, likely the most commonly claimed is for water to maintain fish habitat. Although the method for quantifying these

1 See, e.g., United States v. Washington, 853 F.3d 946, 958 (9th Cir. 2017); Treaty with Nisquallys, Nisquallys-U.S., art. III, Dec. 26, 1854, 10 Stat. 1132 [hereinafter Treaty of Medicine Creek]; Treaty with the Flatheads, Flatheads-U.S., art. III, July 16, 1855, 12 Stat. 975 [hereinafter Treaty of Hell Gate]; Treaty with the Makah Tribe, Makah-U.S., art. IV, Jan. 31, 1855, 12 Stat. 939 [hereinafter Treaty of Neah Bay]; Treaty with the Dwamish, Dwamish-U.S., art. V, Jan. 22, 1855, 12 Stat. 927 [hereinafter Treaty of Point Elliot]; Treaty with the S'klallams, S'kallam-U.S., art. IV, Jan. 26, 1855, 12 Stat. 933 [hereinafer Treaty Point No Point]; Treaty with the Walla-Wallas, U.S.-Walla-Walla, art. I, June 9, 1855, 12 Stat. 945; Treaty with the Yakamas, U.S.-Yakama, art. III, June 9, 1855, 12 Stat. 951; Treaty with the Nez Percés, Nez Percés-U.S., art. III, June 11, 1855, 12 Stat. 957; Treaty with Indians in Middle Oregon, Indians in Middle Oregon-U.S., art. I, June 25,1855, 12 Stat. 963 [hereinafter Treaty with the Tribes of Middle Oregon]; Treaty with the Qui-Nai-Elts, Qui-Nai-Elts-U.S., art. III, July 1, 1855, 12 Stat. 971 [hereinafter Treaty of Olympia]; Treaty with the Klamath, Klamath-Moadoc-U.S.-Yahooskin, art. I, Oct. 14, 1864, 16 Stat. 707; Treaty with the Shoshonnes and Bannacks, BannackShoshonees-U.S., art. I, July 3, 1868, 15 Stat. 673 [hereinafter Treaty of Fort Bridger]. The Executive Orders creating the Coeur d'Alene, Colville, and Spokane Reservations have likewise all been interpreted to have included on-reservation hunting and fishing rights. See United States v. Idaho, 95 F. Supp. 2d 1094, 1109 (D. Idaho 1998); Colville Confederated Tribes v. Walton (Walton I), 647 F.2d 42, 47 (9th Cir. 1981); United States v. Anderson, 591 F. Supp. 1, 5 (E.D. Wash. 1982).

2 Walton I, 647 F.2d at 48; United States v. Adair, 723 F.2d 1394, 1408 (9th Cir. 1984); United States v. Anderson, 736 F.2d 1358, 1365 (9th Cir. 1984).

3 See, e.g., Walton I, 647 F.2d at 47-48. 
rights have evolved over time, ${ }^{4}$ courts have slowly converged on the IFIM/PHABSIM methodology. Although the IFIM/PHABSIM method does not enjoy the de jure recognition of its sister-methodology PIA, the consistent use and acceptance of this method has made it the de facto method for quantifying reserved instream water rights to protect fish habitat. ${ }^{5}$

The purpose of this Article is to provide an explanation of the IFIM/PHABSIM methodology in an effort to put practitioners in the position to apply and, where necessary, critique the method. It proceeds in a chronological fashion; describing from beginning to end the steps necessary to develop a reserved instream water right claim using the IFIM/PHABSIM method. We begin this journey at the planning stage where important legal questions regarding the appropriate quantification standard must be resolved. From there, it launches into a description of the steps to estimate the quantity of water necessary to protect stream habitat using the IFIM/PHABSIM methodology.

\section{DEFINING THE QUANTIFICATION STANDARD}

The initial step in the quantification process is to define the appropriate quantification standard. This step provides the broad legal sideboards that technical investigators use when developing a method for estimating the amount of water necessary for a particular water right. The classic example is the Supreme Court's adoption of the quantification standard for reserved irrigation water rights. ${ }^{6}$ There, the Court concluded that "the only feasible and fair way by which reserved water for the reservations [at issue in that case] can be measured is irrigable acreage." 7 With that, the Supreme Court defined-as a matter of law-that the appropriate quantification standard for reserved irrigation water rights is the "practicably irrigable acreage" standard. ${ }^{8}$ From there, technical investigators set out to develop a methodology to estimate the "amount of water necessary to irrigate all the practicably irrigable acreage on the Reservation ...." Unlike reserved irrigation water rights, the Supreme Court has never defined a single standard for reserved instream water rights. As a result, the quantification standard for instream water rights remains an open question in each adjudication.

4 See Dylan R. Hedden-Nicely, The Historical Evolution of the Methodology for Quantifying Federal Reserved Instream Water Rights for American Indian Tribes, 50 ENVTL L. REV. 205, 210-12 (2020).

5 See discussion infra Part II.

6 Arizona v. California (Arizona $I$ ), 373 U.S. 546, 601 (1963).

7 Id.

8 Id. at 600.

9 Simon H. Rifkind, Special Master Report at 265, Arizona v. California (Dec. 5, 1960) [hereinafter Simon H. Rifkind, Special Master Report]. 
States and non-Indian water users often argue that the reserved instream water rights should be married to the "moderate living standard."10 The Supreme Court has applied this standard to determine the quantity of fish certain northwest tribes are entitled to take pursuant to their treaties. ${ }^{11}$ The moderate living standard entitles those Indian tribes to take the amount of fish necessary to maintain a moderate standard of living for its members, up to $50 \%$ of catchable harvest. ${ }^{12}$ The inference is that since Indian tribes usually do not consume similar quantities of fish as when the treaties were made, the tribes' instream flow rights should be decreased congruent with current fish consumption. ${ }^{13}$ However, while parallels exist between the right to harvest fish and the right to use water, the "'moderate living' standard makes little sense in the context of a water right." 14

First, the moderate living standard is predicated upon the concept of balancing the interests of tribal people against those of non-Indian fishers. The basis for this shared shortage is the fact that the treaties at issue in Washington v. Washington State Commercial Passenger Fishing Vessel Ass'n (Passenger Vessel) guaranteed "the right of taking fish ... in common with all the citizens of the Territory." 15 Justice Stevens found that based upon this language: "[t]he logic of the $50 \%$ ceiling is manifest. For an equal division-especially between parties who presumptively treated with each other as equals-is suggested, if not necessarily dictated, by the word 'common' as it appears in the treaties." 16 In contrast, there is no treaty language stating that tribal water rights are to be shared "in common" with non-Indians. Just the opposite, a cornerstone of the Winters doctrine is that quantification of reserved rights is not predicated on the balancing of the interests of non-

10 See, e.g., Determination of the Relative Rights of Waters of the Klamath River, Oregon Office of Administrative Hearings for the Water Resources Department, Case No. 285 (Feb. 13, 2007) [hereinafter In re Klamath River, Proposed Order].

11 Washington v. Wash. State Commercial Passenger Fishing Vessel Ass'n (Passenger Fishing Vessel), 443 U.S. 658, 686-87 (1979). Indeed, much of this confusion stems from the Supreme Court's choice to cite Arizona I, 373 U.S. at 546-a water rights case-as support for the moderate living standard. Passenger Fishing Vessel, 443 U.S. at 686.

$12 I d$. at $686-87$.

13 See, e.g., State of Idaho's Memorandum in Support of Motion for Summary Judgment at 71-73, In re the General Adjudication of the Rights to the Use of Water from the Coeur d'Alene-Spokane River Basin Sys., No. 49576, Subcase No. 91-7755 (D. Idaho Oct. 20, 2016) [hereinafter In re CSRBA, Idaho's Memo for S.J.].

14 In re Klamath River, Proposed Order, supra note 10, at 10.

15 Passenger Fishing Vessel, 443 U.S. at 658 (emphasis added). See generally Treaty of Medicine Creek, supra note 1, at art. III; Treaty of Hellgate, supra note 1, at art. III; Treaty of Neah Bay, supra note 1, at art. IV; Treaty of Point Elliot, supra note 1, at art. V; Treaty Point No Point, supra note 1, at art. IV; Treaty with the Walla Wallas, supra note 1, at art. I; Treaty with the Yakamas, supra note 1, at art. III; Treaty with the Nez Percés, supra note 1, at art. III; Treaty with the Tribes of Middle Oregon, supra note 1, at art. I; Treaty of Olympia, supra note 1, at art. III; Treaty with the Klamath, supra note 1, at art. I; Treaty of Fort Bridger, supra note 1, at art. IV.

16 Passenger Fishing Vessel, 443 U.S. at 686 n.27. 
Indian water users. ${ }^{17}$ Instead, the quantity reserved is the amount "sufficient to accomplish the purposes of the reservation." 18

Second, the moderate living standard assumes that the Tribe's fishing rights can be lost for nonuse. Indeed, writing in rather morbid terms, Justice Stevens noted that "[i]f . . . a tribe should dwindle to just a few members, or if it should find other sources of support that lead it to abandon its fisheries, a $45 \%$ or $50 \%$ allocation of an entire run ... would be manifestly inappropriate . ..."19 In contrast, a basic tenant of the Winters doctrine is that federal reserved water rights cannot be lost for nonuse and exist for both current and future water needs. ${ }^{20}$

Finally, and most importantly, unlike a treaty fishing right, "[r]educing the water level below a level which would support a productive habitat would have the result of abrogating the reserved [water] rights." 21 Indeed, the right to take fish is fundamentally different from an appurtenant water right to support fish habitat because, unlike the fishing right per se,

[T] he reserved [water] right could [not] be reduced without completely frustrating the purpose of the $[R]$ eservation .... For example, if the [T] ribes' $50 \%$ allocation of the harvestable fish run ... [is] reduced to a $35 \%$ allocation, the reserved [fishing] right would still survive after the reduction. In contrast, the ... reserved water right does not readily lend itself to such a reduction. ${ }^{22}$

The difference is manifest: "a reduction of the take of fish allotted to the tribes means less fish ... a reduction [in the water quantity] below [the amount necessary to maintain] a healthy habitat means no fish, because they cannot survive." ${ }^{23}$ As a result, the moderate living standard simply has no applicability to the quantification of reserved instream minimum flow water rights.

The upshot is that courts have rejected linking the quantification of tribal instream water rights to the quantification of tribal fishing rights. Rather, courts have universally linked these reserved instream water rights to stream habitat. ${ }^{24}$ Tribal claimants in earlier cases such as Big Horn ${ }^{25}$ Anderson, ${ }^{26}$ and Acquavella ${ }^{27}$ argued the quantification

17 Winters v. United States, 207 U.S. 564, 576-77 (1908); Cappaert v. United States, 426 U.S. 128, 138-39 (1976); New Mexico v. Aamodt, 537 F.2d 1102, 1113 (10th Cir. 1976); In re The Gen. Adjudication of All Rights to Use Water in the Big Horn River Sys., 753 P.2d 76, 111 (Wyo. 1988); Wash. Dep't of Ecology v. Yakima Reservation Irrigation Dist., 850 P.2d 1306, 1317 (Wash. 1993).

18 Cappaert, 426 U.S. at 138-39.

19 Passenger Fishing Vessel, 443 U.S. at 687.

20 See Arizona I, 373 U.S. 546, 601 (1963); FeLIX COHEN, COHEN'S HaNdBook OF FEDERAL INDIAN LAW 1205 (Neil Jessup Newton ed., 2012).

21 United States v. Adair, 187 F. Supp. 2d 1273, 1277 (D. Or. 2002).

$22 \mathrm{Id}$.

23 In re Klamath River, Proposed Order, supra note 10, at 11.

24 See Hedden-Nicely, supra note 4, at 232-33, 242, 244-245.

25753 P.2d 76 (Wyo. 1988). 
standard should be for sufficient water to provide for "optimum conditions for fish habitat." 28 However, application of the "optimum habitat" standard proved troublesome. For example, the Special Master in Big Horn repeatedly questioned its interrelationship with what he saw as the goal of determining "minimum" flows for the streams. ${ }^{29}$ The root of the Special Master's trepidation seemed to have been his misunderstanding that the quantification was for the "optimum stream flow," rather than the amount of flow necessary to provide "optimal habitat." 30 Eventually, the confusion caused by the "optimum habitat" standard in Big Horn and other cases caused the United States and tribes to move away from its use in more recent adjudications. ${ }^{31}$

In reevaluating how to articulate the proper quantification standard, investigators went back to first principles of federal reserved water rights law, which holds that a tribe is entitled to the "amount of water necessary to fulfill the purpose of the reservation."32 Discerning the purposes for the creation of an Indian reservation requires determination of the mutual intent of both the United States and the tribes. ${ }^{33}$ Where tribes have reserved hunting and fishing rights, they are "entitled to as much water on the Reservation lands as they need to

26591 F. Supp. 1 (E.D. Wash. 1982).

27 No. 77-2-01484-5 (Wash. Super. Ct. Dec. 22, 1994).

28 Transcript of Record Vol. 71 at 6343 , In re The Gen. Adjudication of All Rights to Use Water in the Big Horn River Sys., No. 4993 (D. Wyo. June 2, 1981) Thereinafter Big Horn, Test. D. Vogel (Part D) (emphasis added); United States v. Anderson, 591 F. Supp. 1, 5 (E.D. Wash. 1982); Affidavit of Dell Simmons at 4, Wash. Dept. of Ecology v. Acquavella (Wash. Super. Ct. July 29, 1990) [hereinafter Acquavella, Aff. D. Simmons]; Amendment to Memorandum Opinion Re; Motions for SJ Dated May 22, 1990 at 55, State of Washington Dep't of Ecology v. Acquavella, No. 77-2-01484-5 (Wash. Super. Ct. Oct. 22, 1990); see also In re CSRBA, Idaho's Memo for S.J., supra note 13, at 10; M.R. BARBER ET aL., PRedicting the EFfect of Reduced Streamflow on RaINBow Trout, Brown Trout, and Scullpin Populations in Chamokane Creek Using Instream Flow INCREMENTAL METHODOLOGY (IFIM) ii (1988) ("The purpose of this study was to: (1) determine the optimum flow for brown trout (Salmo trutta Linnaeus), rainbow trout (Salmo gairdneri Richardson), and sculpins ....") (emphasis added).

29 Transcript of Record Vol. 72 at 6426, In re The Gen. Adjudication of All Rights to Use Water in the Big Horn River Sys., No. 4993 (D. Wyo. June 2, 1981) [hereinafter Big Horn, Test. D. Vogel (Part II)]; Teno Roncalio, Report Concerning Reserved Water Right Claims By and On Behalf of the Tribes of the Wind River Indian Reservation, Wyoming at 242, In re The General Adjudication of All Rights to Use Water in the Big Horn River System, No. 4993 (D. Wyo. Dec. 15, 1982) Thereinafter Big Horn, Special Master Report] ('Once again we find the subtle advancement and purpose to be the 'maximization' of a goal rather than the establishment of normal or ordinary levels."); see also Amendment to Memorandum Opinion Re: Motions for Partial Summary Judgment Dated May 22, 1990 at 55, No. 77-2-01484-5 (Wash. Super. Ct. Oct. 22, 1990) [hereinafter Acquavella, Amended Memo Opinion (Yakima River)] (holding that the Yakama Nation is entitled to "the minimum amount of instream flow that is absolutely necessary for the mere maintenance of fish life in the river").

30 Big Horn, Test. D. Vogel (Part II), supra note 29, at 6426.

31 See infra note 37 and accompanying text.

32 Cappaert, 426 U.S. 128, 141 (1976); see also Walton I, 647 F.2d 42, 47 (9th Cir. 1981); Anderson, 736 F.2d 1358, 1362 (9th Cir. 1984).

${ }^{33}$ Adair, 723 F.2d 1394, 1408 n.13 (9th Cir. 1984). 
protect their hunting and fishing rights."34 Protection of those rights requires fish and other animals continue "to exist [in all life cycles] in a stable, sound state ...."35 which requires sufficient water "in time and location, to assure the existence of a habitat sustaining a viable and selfrenewing population of the treaty species ..."36 As a result, claimants in contemporary cases have re-centered the quantification standard to the amount of "instream flows necessary to provide for a healthy and productive habitat for . . . fish species in the streams and rivers . . .."37

Of course, this qualitative target simply begs the question: how much water is necessary to provide a healthy and productive habitat? To date, no quantification method has been universally accepted by the judiciary in the United States. Although this ambiguity creates uncertainty as to the proper methodology, it also allows for more flexibility to develop a quantification method more uniquely tailored to the specific needs of the subject reservation. The result has been quantification methods that have developed organically over time congruent with available technology and scientific understanding at the time each case has taken place. ${ }^{38}$ This process has caused the methodology to evolve over time, slowly converging on the incremental methodology (IFIM) using the Physical Habitat Simulation Model (PHABSIM). ${ }^{39}$

\section{The CONTEMPoRARY METHOD: THE COMBINED INSTREAM FLOW INCREMENTAL METHOD (IFIM) AND PHYSICAL HABITAT SIMULATION (PHABSIM) METHODOLOGY}

The IFIM/PHABSIM methodology is the most widely used method for the quantification of reserved minimum instream flow water rights

34 United States v. Adair, 478 F. Supp. 336, 345 (D. Or. 1979).

35 Transcript of Record at I-17, In re the Determination of the Relative Rights of the Waters of the Klamath River, a Tributary of the Pac. Ocean, No. 277 (State of Oregon Office of Administrative Hearings for the Water Resources Department Dec. 4, 2009) [hereinafter In re Klamath River, Aff. D. Reiser].

36. In re Klamath River, Proposed Order, supra note 10, at 12.

37 In re Klamath River, Aff. D. Reiser, supra note 35, at I-11 to -12 ; see also Transcript of Record at 2-3, In re the Gen. Adjudication of the Rights to the Use of Water from the Coeur d'Alene-Spokane River Basin Sys., No. 49576, Subcase No. 91-7755 (D. Idaho Oct. 20, 2016) [hereinafter In re CSRBA, Aff. D. Reiser]. Practically, the "optimum habitat" quantification standard and the "healthy and productive habitat" standard result in very similar outcomes; in each case investigators set out to determine-month-by-month-the quantity of water that would maximize the available habitat given hydrological conditions for the stream. In re Klamath River, Aff. D. Reiser supra note 35, at VII-59; Big Horn, Test. D. Vogel (Part II), supra note 29, at 6427-29. The exception is Anderson wherein investigators recommended a "limiting" flow of $27.7 \mathrm{cfs}$ for every month of the year except March and April. See Hedden-Nicely, supra note 4, at 226; see BARBER ET AL., supra note 28 , at $82,96-97$. The limiting flow corresponded to the quantity of water necessary to maintain habitat in the lowest-flow month of August. Id.

38 See infra Part III.

39 See generally Hedden-Nicely, supra note 4, at 244-45. 
today. ${ }^{40}$ The purpose of the methodology is to "simulate a relationship between streamflow and physical habitat for various lifestages of a species of fish ...."41 The methodology has "two basic components ... [1] the hydraulic [component] and [2] [the] habitat simulation] [component]," which are estimated by "utilizing defined hydraulic parameters and habitat suitability criteria." 42 The overall goal is to claim the quantity of water-usually a streamflow ${ }^{43}$ measured in cubic feet per second (cfs) ${ }^{44}$ - that corresponds to the amount of water necessary-on a reach-by-reach basis-to provide a healthy habitat for the highest priority lifestage of a target species present in the reach. The method proceeds in four broad steps: "(1) study site selection [and other preliminary matters], (2) field data collection, (3) development of suitability criteria, and (4) hydraulic simulation and habitat prediction." 45

\section{A. Preliminary Matters: Selection of Claim Reaches, Identification and Prioritization of Target Species, and Identification of Species Distribution Periodicity}

The IFIM/PHABSIM methodology requires the development of a few preliminary decisions before actual data collection or modeling may take place. The first issue centers on the determination of the streams that will require instream flow water rights. Claim reaches are selected in consultation with the tribes based upon site-specific information regarding fish populations as well as those locations that "are important to the Tribes' fishing, hunting, trapping, and gathering [activities]." 46

40 A primary factor for a court in determining whether to accept a scientific methodology is the general acceptance of that methodology within the scientific community. Daubert v. Merrell Dow Pharm., Inc., 509 U.S. 579, 594 (1993). Accordingly, a major advantage of the IFIM/PHABSIM method is that "it is the most widely recognized method in North America." In re Klamath River, Aff. D. Reiser, supra note 35, at VII-1. Another advantage of the method is that it is widely used by state agencies around the West, making it more difficult for those same states to challenge its use to quantify federal reserved minimum instream flows. See, e.g., Big Horn, Test. D. Vogel (Part I), supra note 28 , at 6343 .

41 R. T. Milhous et al., Physical Habitat Simulation System Reference Manual V. II, at I.3 (1989).

42 Id. at I.5.

43. The terms "streamflow," "flow," and "discharge" are synonymous. Each refers to "the volumetric rate of flow of water (volume per unit time) in an open channel." D. PHILL TURNIPSEEd \& VERnon B. SAUER, Discharge MEASUREMENTS AT GaGing Stations 1 (2010).

44 A cubic foot per second is defined as: "[a] standard measure of the total [volume] of water [measured in cubic feet] passing by a particular location of a river, canal, pipe, or tunnel during a one second interval." In re Klamath River, Aff. D. Reiser, supra note 35, at app. A-5.

45 Acquavella, Aff. D. Simmons, supra note 28, at 4.

46 In re Klamath River, Aff. D. Reiser, supra note 35, at VII-9; see also Big Horn, Test. D. Vogel (Part I), supra note 28 , at $6360,6366$. 


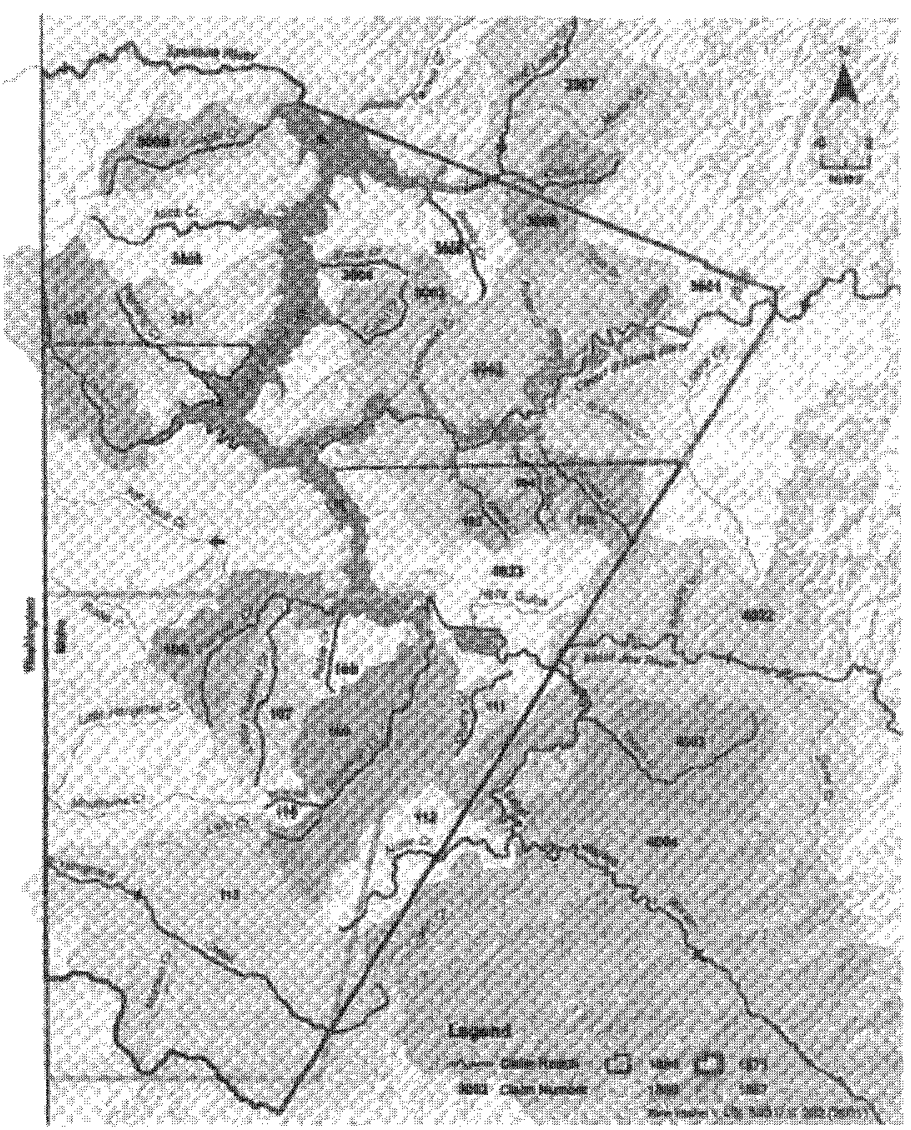

\section{Figure 1. Example Claim Reach Map, Coeur d'Alene Reservation, Idahoti}

The target species must likewise be identified because habitat for different species may require differing-and sometimes conflictingquantities of water. The target species are selected in consultation with the tribes and are usually those species that are native to the stream, were traditionally harvested by the tribe, and either continue to exist or have a reasonable likelihood of reintroduction to the watershed. ${ }^{4}$

One controversy that often arises is whether claims must be based solely upon native fish species that were traditionally relied upon by the

47 h re CSRBA, Aft. D. Reises, supra note 37.

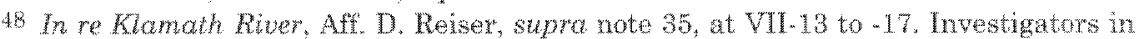
Anderson suggested that target species were identhed based upon 1) their economic value; 2 ) their sensitivity to envixomental change; andor 5 ) because they are a primary food source for hish valued under eriteria (1) or (2). BARBER Er AL. aupro note 28, at 30. Based upon this criteria, ranbow trout and brown trout were selected for their economu value and seulpins were chosen because they were a primary food source tor trout in Chamokane Creok. Id at 31,39 . 
tribes at the time the reservation was created or whether water rights for introduced fish species are sometimes appropriate..$^{49} \mathrm{Often}$, this issue arises when states and/or the federal government has either introduced non-native fish species to a waterway that competes with the native fish population or eliminated the native fish altogether. For example, in Big Horn, the State of Wyoming had introduced rainbow trout, brook trout, and brown trout to streams that flowed through the Wind River Reservation, all of which competed for habitat with the native cutthroat population. ${ }^{50}$ As a result, members of the Wind River Reservation came to depend upon those species as well as native cutthroat for subsistence. A similar issue arose in Walton, where the court discussed how the erection of Grand Coulee Dam extirpated the salmon population at the Colville Reservation. ${ }^{51}$ The Tribes had traditionally relied upon both salmon and trout, and had introduced lahonton trout to Omak Lake within the reservation. ${ }^{52}$

In both Big Horn and Walton the question was whether the Tribes could claim a water right for the introduced. species. $^{53}$ Although not a central issue in Big Horn, the Special Master there found that a water right for introduced species was appropriate because the Wind River Tribes shared an interest in the entire fishery, regardless of species. ${ }^{54}$ The Ninth Circuit provided more analysis in Walton, where it concluded that the Tribes were entitled to "an implied reservation of water from No Name Creek for the development and maintenance of replacement fishing grounds." 55 According to the Ninth Circuit, the water right for replacement fishing grounds was not a new water right but instead a change in use of the Tribes' water right that was reserved for the Tribes' traditional fishing grounds. ${ }^{56}$ The court acknowledged that "access to fishing grounds was one purpose for the creation of the Colville Reservation" and thus recognized that "the Tribe has a vested property right in reserved water ...."57 Although the court recognized that-due to the actions of the United States-the Tribes no longer enjoyed the ability to fish in their traditional manner, once the Tribes' water rights vested, "subsequent acts making the historically intended use of the water unnecessary do not divest the Tribe of the right to the water." 58 Instead, the Tribes could change the use of some or all of that vested

\footnotetext{
49 Big Horn, Test. D. Vogel (Part II), supra note 29, at 6436.

50 Id.

51 See Walton I, 647 F.2d 42, 45 (9th Cir. 1981).

52 Id.; see also Hedden-Nicely, supra note 4, at 212. 48.

53 Big Horn, Test. D. Vogel (Part II), supra note 29, at 6436; see Walton I, 647 F.2d at

54 Big Horn, Test. D. Vogel (Part II), supra note 29, at 6437.

55 Walton $I, 647$ F.2d at 48.

$56 \mathrm{Id}$.

$57 I d$.

$58 I d$.
} 
water right to support the newly introduced trout spawning grounds on No Name Creek. 59

The final preliminary consideration lies in the prioritization of the identified target species and fish lifestages. The ultimate result of the IFIM/PHABSIM analysis is a single quantity of water. However, "[f]or any given reach of stream, there could potentially be [several] target fish species present.... [and] multiple lifestages might exist for each species within the same reach." 60 This becomes problematic when "the flow needs of fish vary by lifestage [and species]."61 Fish species are prioritized based upon "the cultural, ceremonial, and management values of the ... Tribes, as well as state and federal recovery and management goals." 62 In contrast, fish lifestage is prioritized "based on their biological importance in maintaining the population viability of the target fish species." 63 This results "in the ranking of the lifestages from highest (most important) to lowest as follows: spawning (first priority); adult (second priority); juvenile (third priority); and fry (fourth priority)."64 In general, conflict between lifestage prioritization and species prioritization is resolved in favor of the lifestage priority. ${ }^{65}$

Once the target fish species have been identified and prioritized, and the stream reaches where claims will be made have been located, the data collection process may begin.

\section{B. Data Collection Methodology}

Data necessary for the IFIM/PHABSIM methodology is primarily collected-on a reach-by-reach basis-through fieldwork. 66 Figure 2 depicts how a claim reach is broken down into component parts for the data collection process.

59 See id. at $48-49$.

60 In re Klamath River, Aff. D. Reiser, supra note 35, at VII-32.

61 Id. ("Fry, for example, cannot withstand as high a velocity of water as can juvenile or adult fish and seek slower waters. Therefore, the amount of flow needed to provide fry habitat in a stream is typically less than that needed for juvenile and adult habitat. For spawning habitat, the amount of flow needed depends in large part on the location and amount of spawning gravel, and the amount of flow required to provide suitable water depths and velocities over such gravels. This may require different flows than those for either juvenile or the adult lifestages.").

62 Id. at VII-35.

63 Id. at VII-33.

64 Id. For a comprehensive explanation of the rational for this ranking, see id. at VII$33-35$.

65 Id. at VII-36. Usually, lifestage prioritization provides that spawning is the highest priority lifestage, followed by adult, juvenile, and fry (in order of descending priority). See $i d$. at VII-34. Additionally, the incubation stage is the highest lifestage prioritization for the month following a spawning event, which is taken to be $2 / 3$ of previous month's spawning flow. See id. at VII-33 to -35, VII-37.

66 Id. at VII-45; see also Big Horn, Test. D. Vogel (Part 1), supra note 28, at 6365; BARBER ET AL., supra note 28, at 31; Acquavella, Aff. D. Simmons, supra note 28, at 4. 


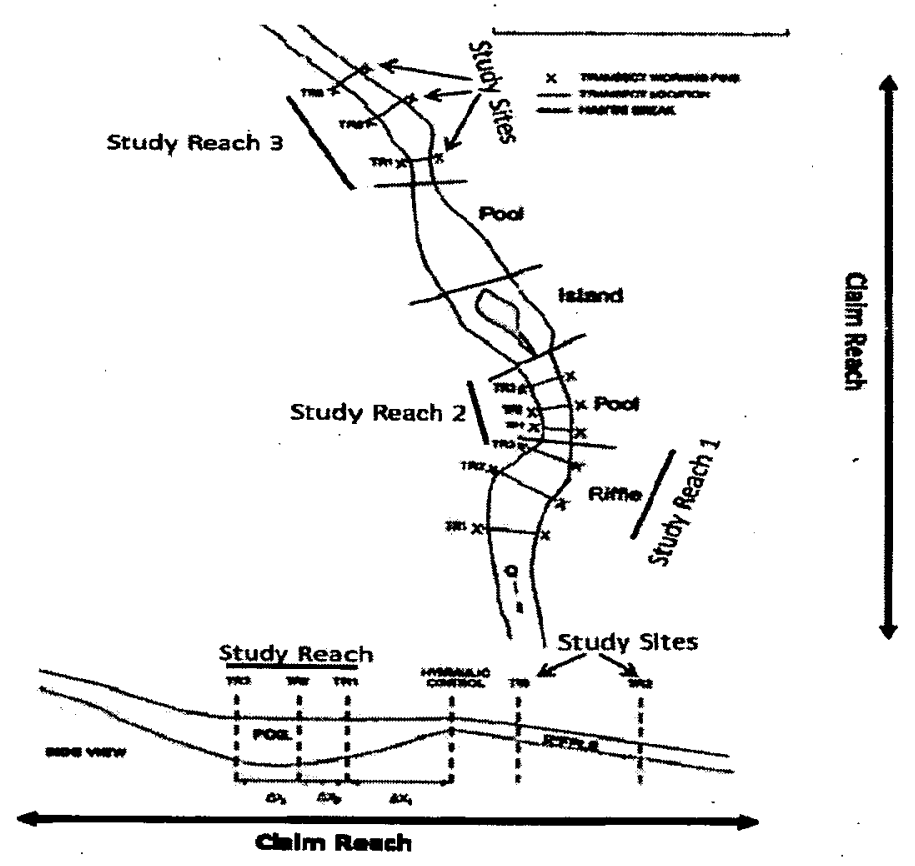

Figure 2. Example Claim Reach ${ }^{67}$

As depicted in Figure 2, a claim reach is broken into a series of "study reaches" to be surveyed and habitat mapped to determine the composition of habitat types. ${ }^{68}$ Boundaries between study reaches are placed at "habitat breaks" where the stream experiences significant changes in gradient, sediment supply, sinuosity, aggradation/degradation, channel shape, or substrate material. 69 Within each study reach a number of "study sites" are then randomly selected.70 The study sites are the locations that contain the survey transect and between which field data are collected. ${ }^{71}$ Survey transects are developed

67 In re Klamath River, Aff. D. Reiser, supra note 35, at VII-52 (with labels added by the author).

68 Id. at VII-9; see also In re CSRBA, Aff. D. Reiser, supra note 37, at 9, 11, 29. "Study reaches" were referred to as "stream reaches" in the Big Horn adjudication while they were referred to as "study segments" in the 1988 Anderson report and by Dell Simmons in Acquavella. See Big Horn, Test. D. Vogel (Part I), supra note 28, at 6365; Acquavella, Aff. D. Simmons, supra note 28, at 4-5; BARBER ET AL., supra note 28, at 35.

69 In re Klamath River, Aff. D. Reiser, supra note 35, at VII-10; BARBER ET AL., supra note 28, at 31-32; Big Horn, Test. D. Vogel (Part I), supra note 28, at 6366-67; Acquavella, Aff. D. Simmons, supra note 28 , at 4-5.

${ }^{70}$ In re Klamath River, Aff. D. Reiser, supra note 35, at VII-9; Acquavella, Aff. D. Simmons, supra note 28 , at 5.

71 In re Klamath River, Aff. D. Reiser, supra note 35, at VII-8, VII-46. "Study sites" were referred to a "study reaches" in the 1988 Anderson report. See BARBER ET AL., supra note 28 , at 36 . 
at the study sites using standard surveying techniques. ${ }^{72}$ Working pins are placed above the high-water mark on either side of the stream transect and elevation measurements are taken-relative to the elevation of those pins-at regular intervals across the stream to establish the channel profile. ${ }^{73}$

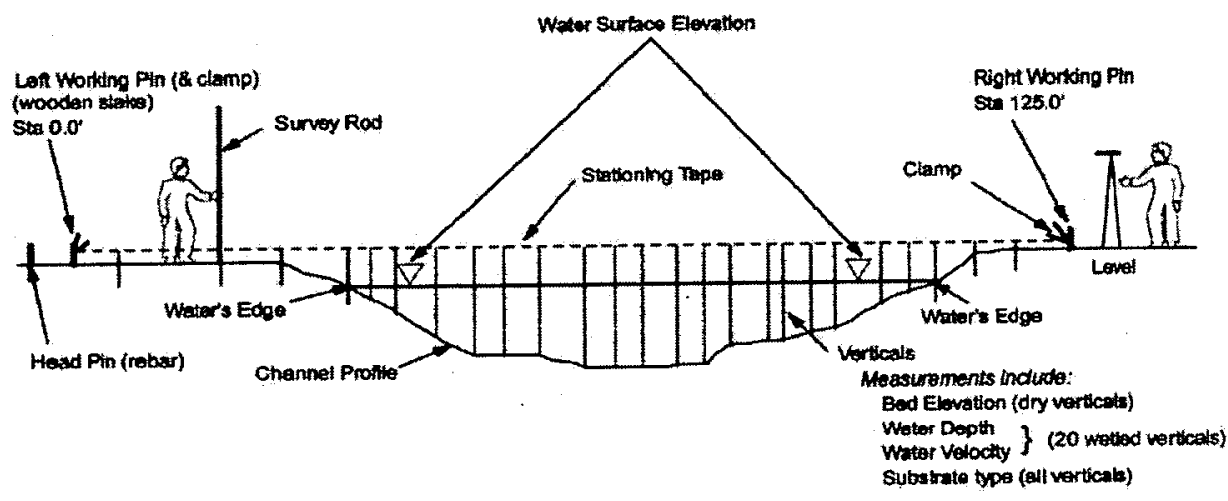

\section{Figure 3. Illustration of Survey Technique and Data Collection at Each Study Site ${ }^{74}$}

Once study sites have been identified, data collection efforts center on three separate but interrelated facets of the IFIM/PHABSIM modeling process: 1) channel hydraulics; 2) biological parameters (habitat suitability and species periodicity); and 3) stream hydrology. Importantly, data are updated through subsequent field collection efforts over the course of several years to incorporate any variability that may exist. ${ }^{75}$

The hydraulic parameters. The primary physical inputs to the IFIM/PHABSIM model are channel depth, velocity, and streambed substrate, which are collected "at regular intervals across the transect (each interval referred to as 'verticals' or 'cells.)" "76 "The distribution of depth across the stream is obtained by subtracting the known ground/streambed elevations from the predicted surface elevation at

72 In re Klamath River, Aff. D. Reiser, supra note 35, at VII-49; see BARBER ET AL., supra note 28, at 39; Big Horn, Test. D. Vogel (Part I), supra note 28, at 6386-88; Acquavella, Aff. D. Simmons, supra note 28, at 6.

73 In re Klamath River, Aff. D. Reiser, supra note 35, at VII-50; see BARBER ET AL., supra note 28, at 39-40; Big Horn, Test. D. Vogel (Part I), supra note 28, at 6388; Acquavella, Aff. D. Simmons, supra note 28, at 6 .

74 In re Klamath River, Aff. D. Reiser, supra note 35, at VII-50.

75 Id. at VII -44 to -45 .

76 Id. at VII-52; see also BARBER ET AL., supra note 28, at 42; Big Horn, Test. D. Vogel (Part I), supra note 28, at 6389. 
each transect." 77 Velocity is measured using instrumentation at the same verticals where stream depth is estimated. ${ }^{78}$ Finally, channel substrate is observed within each cell. ${ }^{79}$ These measurements are taken at least three times at different times of the year to collect information regarding depth, velocity, and substrate at different flow stages. 80

The biological parameters. Data regarding fish species distribution and lifestage periodicity are collected at each study reach. ${ }^{81}$ Species distribution describes which "target fish species [are] found within each claim reach . ..."82 Likewise, lifestage periodicity describes the specific lifestages occurring in specific geographic areas in each month of the year. ${ }^{83}$ These data are necessary because a primary assumption underlying the IFIM/PHABSIM methodology is that fish will be positioned at locations of optimal depth and velocity.

Species distribution and lifestage periodicity data are gathered from published and unpublished sources; from fish biologists at state, federal, and tribal agencies; and direct (field) observations and technical studies performed in the sub-basin. ${ }^{84}$ The field collection method is outlined in detail in Ken Bovee's 1986 biological report.85 More generally, the method requires a snorkeler to move upstream through the study reach, marking the fishes location and noting their species and lifestage; while, a second person takes depth, velocity, and substrate measurements at those particular sites. ${ }^{86}$ The final result is a species periodicity chart, as exemplified in Figure 4, for each target species located in each claim reach. 87

77 Acquavella, Aff. D. Simmons, supra note 28, at 8.

78 In re Klamath River, Aff. D. Reiser, supra note 35, at VII-53.

79 Id. at VII -43 .

80 Id.; Big Horn, Test. D. Vogel (Part II), supra note 29, at 6418.

81 In re Klamath River, Aff. D. Reiser, supra note 35, at VII-17, VII-43; In re CSRBA, Aff. D. Reiser, supra note 37, at 9, 11; Big Horn, Test. D. Vogel (Part II), supra note 29, at 6394; Acquavella, Aff. D. Simmons, supra note 28, at 7; BARBER, ET AL., supra note 28, at 26.

82 In re Klamath River, Aff. D. Reiser, supra note 35, at VII-17 to -18.

83 Id. at VII-17.

84 Id. at VII-18, VII-27 to -28; BARBER ET AL., supra note 28, at 27, 68; Acquavella, Aff. D. Simmons, supra note 28 , at 7 .

85 KEN BOVEe, U.S. FISH \& WILdLIFE SERV., DEVelopment and EVAluation OF HABITAT SUITABLITY CRITERIA FOR USE IN THE INSTREAM FLOW INCREMENTAL METHODOLOGY 19-56 (1986).

86 In re Klamath River, Aff. D. Reiser, supra note 35, at VII-43. Investigators in the Anderson case estimated fish habitat distribution using electroshocking techniques where one crew employed spot electrofishing while a second crew marked the location of each fish and took measurements of depth, velocity, and substrate material. BARBER ET AL., supra note 28 , at $48-49$. Investigators in the Big Horn adjudication did not conduct site-specific fish distribution data, opting instead to rely upon more general regional information already developed by Dr. Robert Behnkeat from Colorado State University. Big Horn, Test. D. Vogel (Part II), supra note 29, at 6438.

87 See also BARBER ET AL., supra note 28, at 28-30. 


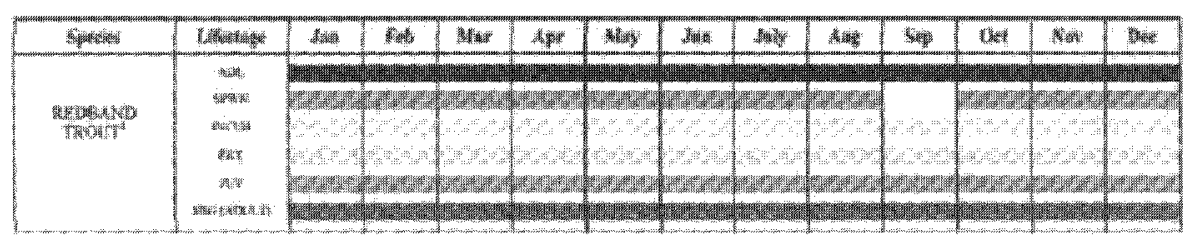

\begin{tabular}{|c|c|c|c|c|c|c|c|c|c|c|c|c|c|}
\hline 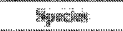 & 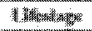 & sam & Fin & then & Ay & Max & Mnin & suly & Mus & Alse & Nois & Wines & 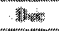 \\
\hline 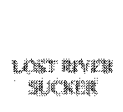 & 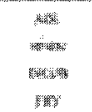 & & & & $\mathrm{CH}^{2}$ & 4 & mere & 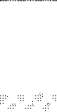 & & & & & \\
\hline & 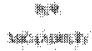 & 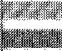 & 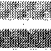 & 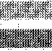 & A & 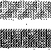 & 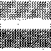 & & refes & The & & & 10. \\
\hline
\end{tabular}

Figure 4. Example Lifestage Periodicity Charts for Two Target Species in the Upper Klamath Basin, Oregon ${ }^{8}$

The hydrologic parameters. In addition to the hydraulic and biological parameters, TFIM/PHABSIM requires information related to the hydrology-the stream's flow-at each study site.89 Hydrology data may be collected from several sources. In some cases, monthly statistics may already be compled for the claim reaches. ${ }^{90}$ If streamflow statistics are not already available, data may be available from public sources, such as the U.S. Geological Survey or state agenctes. ${ }^{91}$ Data may also be available from the Tribe itself or from private entities. Ultimately, if streamflow data is not readily available, it must be collected in the field. However, "[s]treamflow cannot be measured directly but must be computed from variables that can be measured directly, such as stream width, stream depth, and streamflow velocity." 92 Since investigators already collect stream geometry and velocity data, "Tthe most practical method of measuring [streamflow]" is the "velocity-area method," which "is computed as the product of area and velocity." 93 Essentially, the method's field work is identical to the work already completed:

[the measurement is made by subdividing a stream cross section into segments (sometimes referred to as partial areas, sections, subareas,

\footnotetext{
88 The Klamath Rver, Af. D. Reiger, supra note 35, at VI-29, VI-31.

80 Id. at VIsos.

90 See, e.s.s. ind.

91 For example, federal experts in the Kamath litigation relied upon streamflow statistios that had been provided by the Oregon Water Resources Department. In re Klamah Rute, Prowosed Order, supre note 10, at 20. More generally, the statistos compiled by the U.S. Cealogical Survey are available. USGS Wow Dowa for the Naton,

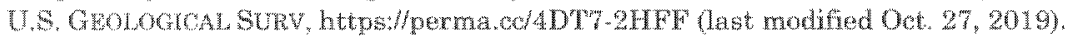

98 TURNIPEED \& SAUER, supwa note 4 , at 1; see also Acquadella, Aff. D. Simmons, supra note 28 , at 8 (noting "it is possible to correlate [streamflow] with water surface

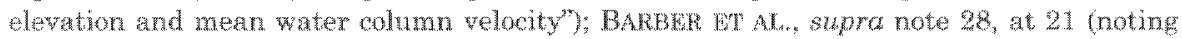
two days were spent in the fold, watking the length of a creeky.

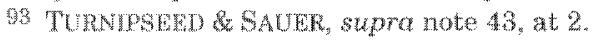


verticals, stations, profiles, panels, or ensembles), ${ }^{94}$ and by measuring the depth and velocity in a vertical within each segment. The total [streamflow] is the summation of the products of the partial areas of the stream cross section and their respective average velocities. This computation is classically expressed by the equation

$$
Q=\sum_{i=1}^{n} a_{i} v_{l}
$$

[Equation 1]

where, $Q$ total [streamflow], in cubic feet per second, ai cross-section area, in square feet, for the $i$ th segment of the $n$ segments into which the cross section is divided, and $v i$ the corresponding mean velocity, in feet per second of the flow normal to the $i$ th segment, or vertical. ${ }^{95}$

This process provides for a single streamflow data point. The point is plotted on a graph-known as a "rating curve"-against stream depth at a particular location (referred to as the stream reach's "stage"). ${ }^{96}$ Over time, sufficient streamflow and stage data are collected and plotted that a relationship between those two parameters can be developed in a rating curve, as depicted in Figure 5.97

94 See supra Figure 3.

95 TURNIPSEED \& SAUER, supra note 43, at 2.

96 RichaRd H. MCCUEN, HYDROLOGIC ANALYSIS AND DESIGN 242 (3d. ed. 2005).

97 Id. 


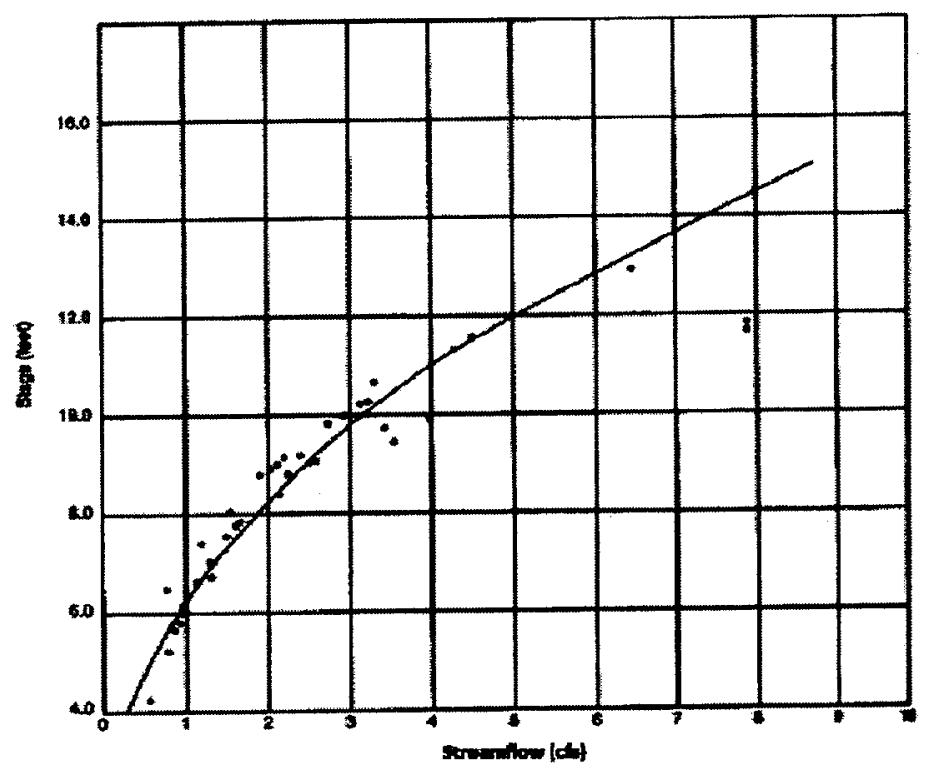

Figure 5. Example Rating Curve ${ }^{98}$

The rating curve allows investigators to estimate streamflow from a known "stage." For example, referring to Figure 5, if the stage of the stream on a given day is 8.0 feet, investigators can estimate the flow to be a little less than $2 \mathrm{cfs}$. The approach is useful because, as noted above, stream stage data is more easily and readily collected on a continuous basis than streamflow per se. ${ }^{99}$ As a result, once the rating curve is developed for the stream reach investigators may estimate streamflow without the extensive field work initially required.

\section{Determination of the Weighted Usable Area: Hydraulic Modeling and Habitat Suitability Curves}

The overall result of the IFIM/PHABSIM methodology is the monthly quantity of water necessary for the highest priority lifestage of the target species present in each claim reach. The methodology has "two basic components ... [1] the hydraulic [component] and [2] the habitat simulations [component]," which are estimated by "utilizing defined hydraulic parameters and habitat suitability criteria."100

The hydraulic component. The primary role of the hydraulic component is to support the habitat component of the IFIM/PHABSIM methodology. The habitat component of the IFIM/PHABSIM methodology requires an analysis of a full range of depth and velocity data for the stream reach. However, it is practically impossible to collect

98 Id. at 608.

99 TURNIPSEED \& SAUER, supra note 43 , at 2.

100 MiLhOUS ET AL., supra note 41, at I.5. 
depth and velocity data in the field across the full range of flows that may exist in a particular stream. The goal of the hydraulic component therefore is to estimate how stream depth and velocity change in a particular stream reach in response to varying streamflow. This is done using a computer modeling process that is completed across a range of possible flows for each study site. As depicted in Figure 6, the model breaks the area between study sites into "a large number of rectangular or trapezoidal cells ... [e]ach [of which] is considered to have a unique combination of depth, velocity, [and] substrate ... at any particular [streamflow]." "101 For example, the cells depicted in Figure 6 could be those cells located between TR2 and TR3 in the riffle depicted in Figure 2. Using stream channel profile data collected at each study transect, the hydraulic model can interpolate "[c]hanges in depth and velocity at unmeasured [streamflows] ... ."102 The process is essentially an inverse of the technique employed to estimate streamflow from known channel geometry and velocity data, as described in Part IV(B). ${ }^{103}$ However, here, the model is given a flow and, based upon the known geometry of the stream, can estimate the channel depth and velocity using a rearranged version of Equation 1. The model iterates this process across a predetermined range of flows and estimates the corresponding depth and velocity.

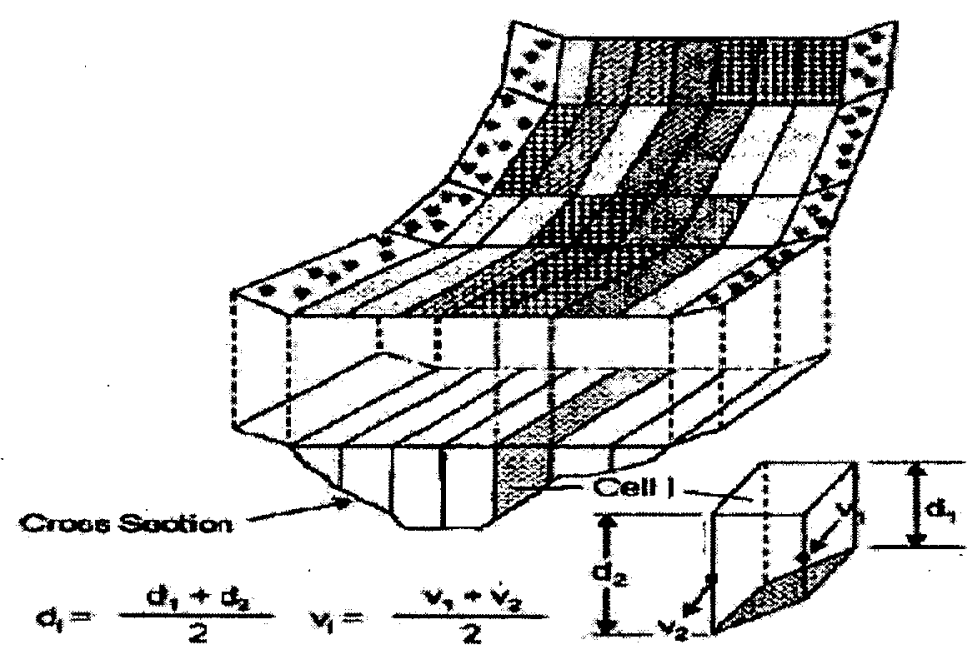

Figure 6. The Cross-Sectional Stream Profile as Broken Down in the IFIM/PHABSIM Method ${ }^{104}$

101 BOVEE, supra note 85 , at 3.

$102 I d$.

103 See supra Part IV.B.

104 In re Klamath River, Aff. D. Reiser, supra note 35, at VII-3. 
The habitat component. Once the hydraulic conditions-the range of possible depths and velocities for a given study site are estimated-the habitat suitability at that site is estimated through the use of habitat suitability curves (HSC). ${ }^{105}$ HSC curves are "probability functions that depict the velocity, depth, and substrate preferences of fish for each species-lifestage combination."106 The curves are predicated upon the assumption that "[e]ach species and lifestage combination has unique requirements or tolerances for velocity, depth, and substrate combinations in a stream."107 As a result, separate HSC curves are developed for depth, velocity, and substrate for each target fish species and each lifestage. ${ }^{108}$

The data collection methods for development of the HSC curves are described in more detail in the Biological Parameters Subsection in Part III(B). ${ }^{109}$ HSC curves are developed through a multistage process for each study reach. ${ }^{110}$ First, researchers conduct a review of any existing data and literature that have resulted in the development of HSC curves for the applicable claim basin and target species. ${ }^{111}$ Those curves are then distributed to experts in fisheries biology who are invited to a roundtable meeting whereat consensus is reached on the development of a set of draft HSC curves for each lifestage of each target species. ${ }^{112}$ These draft HSC curves are then supplemented through field data collection described in Part III(B). ${ }^{113}$

105 See generally id. at VII-41-VII-43; BARBER ET AL., supra note 28, at 47-68; Big Horn, Test. D. Vogel (Part II), supra note 29, at 6435.

106 In re Klamath River, Aff. D. Reiser, supra note 35, at VII-38; see also BARBER ET AL., supra note 28 , at 47 . The expert in the Big Horn adjudication, David Vogel, referred to habitat suitability as "fish preferences." Big Horn, Test. D. Vogel (Part I), supra note 28, at 6360 .

107 In re Klamath River, Aff. D. Reiser, supra note 35, at VII-38; see also BARBER ET AL., supra note 28 , at 47 ("This technique assumes that individuals of a species will select areas of the stream containing the most favorable combination of habitat variables (i.e., velocity, depth, substrate, and cover) ...."); Big Horn, Test. D. Vogel (Part I), supra note 28 , at 6360 ("Once we simulated the hydraulic characteristics in terms of velocity, depth and substrate with the computer, our next step was to actually tie it in with what the fish actually prefer."); Big Horn, Test. D. Vogel (Part II), supra note 29, at 6432 ("we believe the fish will actually go to the conditions that it likes the best").

108 In re Klamath River, Aff. D. Reiser, supra note 35, at VII-39; Big Horn, Test. D. Vogel (Part II), supra note 29, at 6432; BARBER ET AL., supra note 28, at 52-53, 60.

109 See supra notes 82-88 and accompanying text.

110 See generally In re Klamath River, Aff. D. Reiser, supra note 35, at VII-41 to -43 ; BARBER ET AL., supra note 28, at 47-68.

111 In re Klamath River, Aff. D. Reiser, supra note 35, at VII-42; Big Horn, Test. D. Vogel (Part ID), supra note 29, at 6435; BARBER ET AL., supra note 28, at 68-80; Acquavella, Aff. D. Simmons, supra note 28, at 6-7; see also BOVEE, supra note 85, at 57.

112 In re Klamath River, Aff. D. Reiser supra note 35, at VII-42 to -43 . Although $\mathrm{Mr}$. Vogel did not roundtable his data collection with a group of fisheries experts, he did consult with other experts in coming to his conclusions. See Big Horn, Test. D. Vogel (Part II), supra note 29 , at 6435 .

113 See supra Section III(B). 
From the data collected, histograms are developed that group frequency of fish observations into bins based upon how frequently fish are observed at different velocities, depths, or substrates. ${ }^{114}$

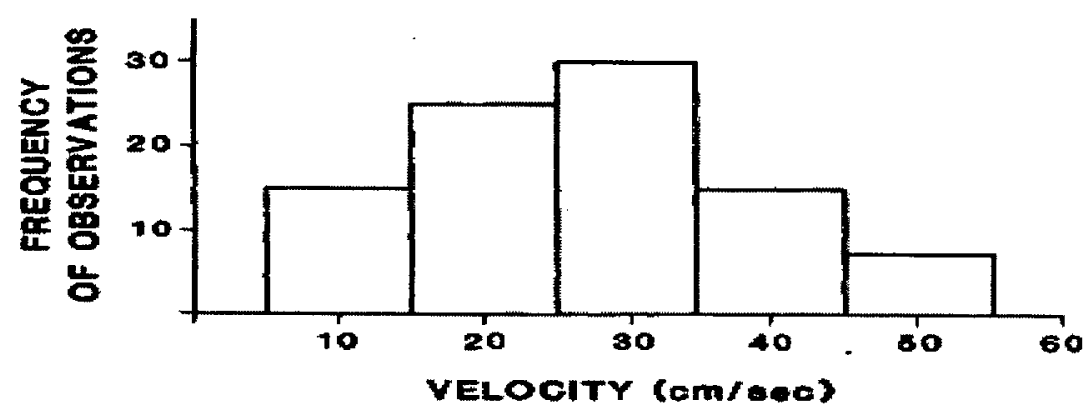

Figure 7. Example Histogram for Frequency of Observation for Differing Stream Velocities ${ }^{115}$

Figure 7 depicts an example of one such histogram that charts numbers of observations against velocity. Similar histograms are developed for depth and substrate at each study site. Various techniques are employed to develop a best-fit line of the histogram to approximate a continuous frequency of observation versus either velocity, depth, or substrate. 116

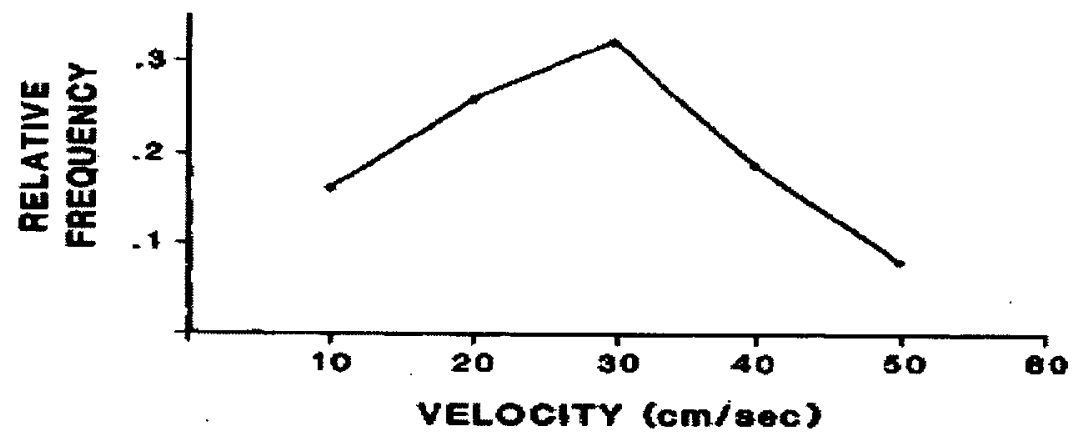

Figure 8. Example Best-Fit Line of Histogram Depicted in Figure $7^{117}$

Finally, the relative frequency is normalized to result in a suitability criteria value of between 0 (no suitable habitat) and 1.0 (optimal habitat), as depicted in Figure 9.118 This process is repeated for depth, velocity, and substrate for each lifestage of each target species at each study reach.

114 BOVEE, supra note 85, at 119 .

116 Id.

116 See id. at 118-22.

117 Id. at 119.

$118 I d$. at 123 . 


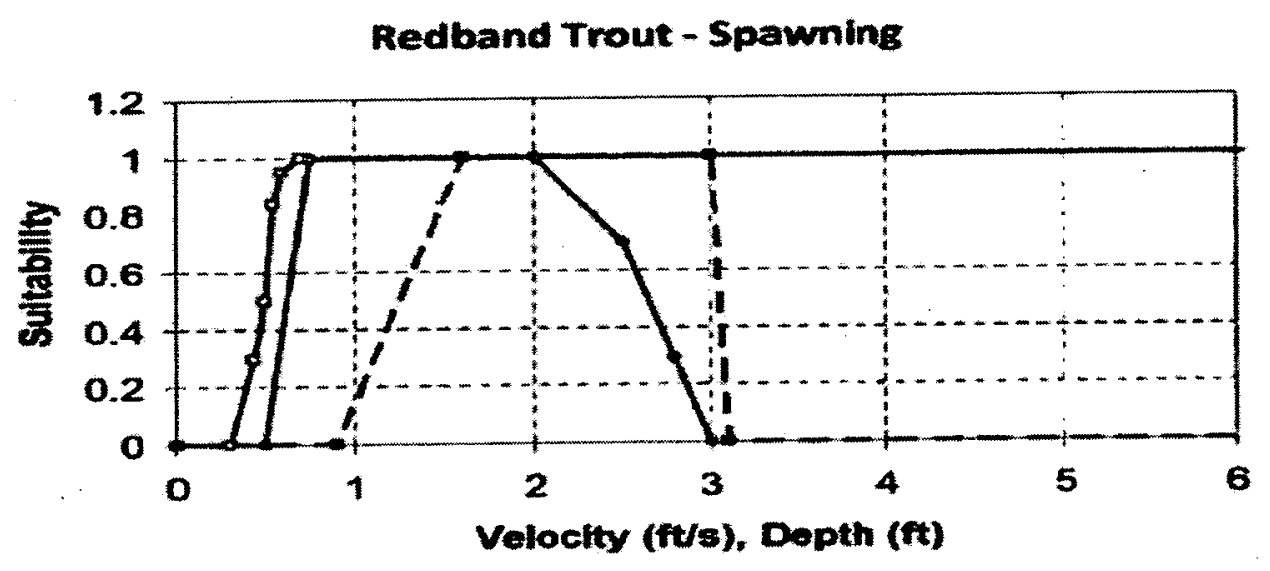

-Volocity (Rovised) - Depth - - - Velocity (Orioinal)

Figure 9. Example Habitat Suitability Curves for Redband Trout Spawning at a Single Study Reach ${ }^{119}$

Integrating the Hydraulic and Habitat Components. The HSC curves are integrated into the hydraulic model to estimate the amount of habitat available for fish-also known as the "weighted usable area"-for a given study area transect and a given flow. The weighted useable area is estimated through the following equation:

$$
W U A(Q)=\sum_{i=1}^{n} A_{i} * C_{i}
$$

[Equation 2]

Where WUA(Q) - or "weighted usable area"-is the physical habitat available for a particular streamflow $Q ; A_{i}$ is the surface area of cell $i$; and $C_{i}$ is the composite suitability for cell $i$. Cell $i$ refers back to the cells of the hydraulic model depicted in Figure 6. $C_{i}$ is estimated through the equation:

$$
C_{i}=H S C_{v} * H S C_{d} * H S C_{c i} \quad \text { [Equation 3] }
$$

Where $H S C_{v}, H S C_{d}$ and $H S C_{c i}$ are the habitat suitability weighting factors for the channel velocity, depth, and index-or substrate--in each cell (i.e., "cell i"). ${ }^{20}$

119 In re Klamath River, Aff. D. Reiser supra note 35, at VII-41.

120 BARBER ET AL., supra note 28, at 81; see also MILHOUS ET AL., supra note 41, at I.9. 
Practically, the equations above are solved through a multi-step process. First, the hydraulic model's output returns information regarding the depth, velocity, and substrate (habitat suitability factors) for a selected flow. As depicted in Figure 10, this output is given on a cell-by-cell basis for the area between two transects at the study site..$^{121}$ Those habitat suitability factors are then compared to the HSC curve for that study site to come to an overall habitat "weighting" for that cell at that particular flow. ${ }^{122}$

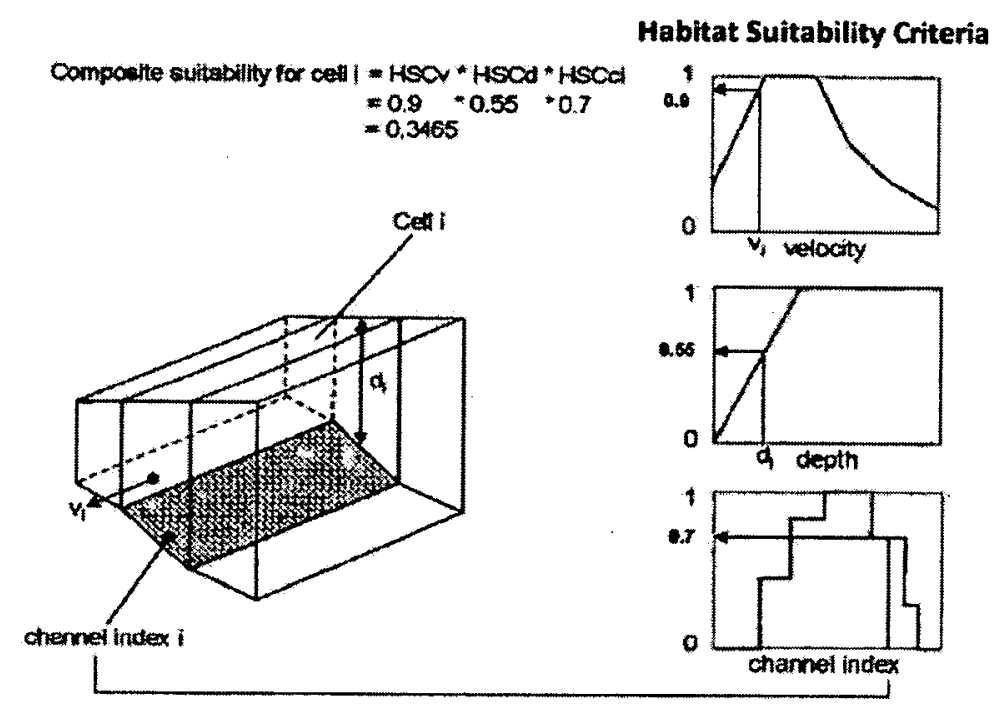

\section{Figure 10. Example of a Water Cell Within a Stream Along with Representative HSC Criteria ${ }^{123}$}

For example, Figure 10 shows a single cell taken from Figure 6. For a given flow, the hydraulic model returns velocity, depth, and substrate estimates, which are charted onto the HSC curves for this study area, returning a $v(i)$ of $0.9, d(i)$ of 0.55 , and a $c i(i)$ of $0.7 .{ }^{124}$ Those are then multiplied together to come to an overall habitat suitability factor of 0.3465 for that particular flow in that cell. The process is repeated at that flow for each cell in the study area shown in Figure 6 and the resulting habitat suitability factors for each cell are summed together to come to an overall composite habitat suitability for the study area at the given flow. This composite suitability is multiplied by linear distance between the transects. ${ }^{125}$ This results in an estimate of available

\footnotetext{
121 See infra Figure 10.

122 See infra Figure 10.

123 Compare Figure 10, with Equation 3.

124 See supra Figure 10.

125 Acquavella, Aff D. Simmons, supra note 28, at 8-9.
} 
habitat, called the "weighted usable area" (WUA). ${ }^{126}$ The available habitat is standardized by expressing it in units of square feet of WUA per 1,000 lineal feet of stream..$^{127}$

This process is iterated at each study site over a range of flows to establish a relationship between weighted usable area and flow. An example of the ultimate result is depicted in Figure 11.

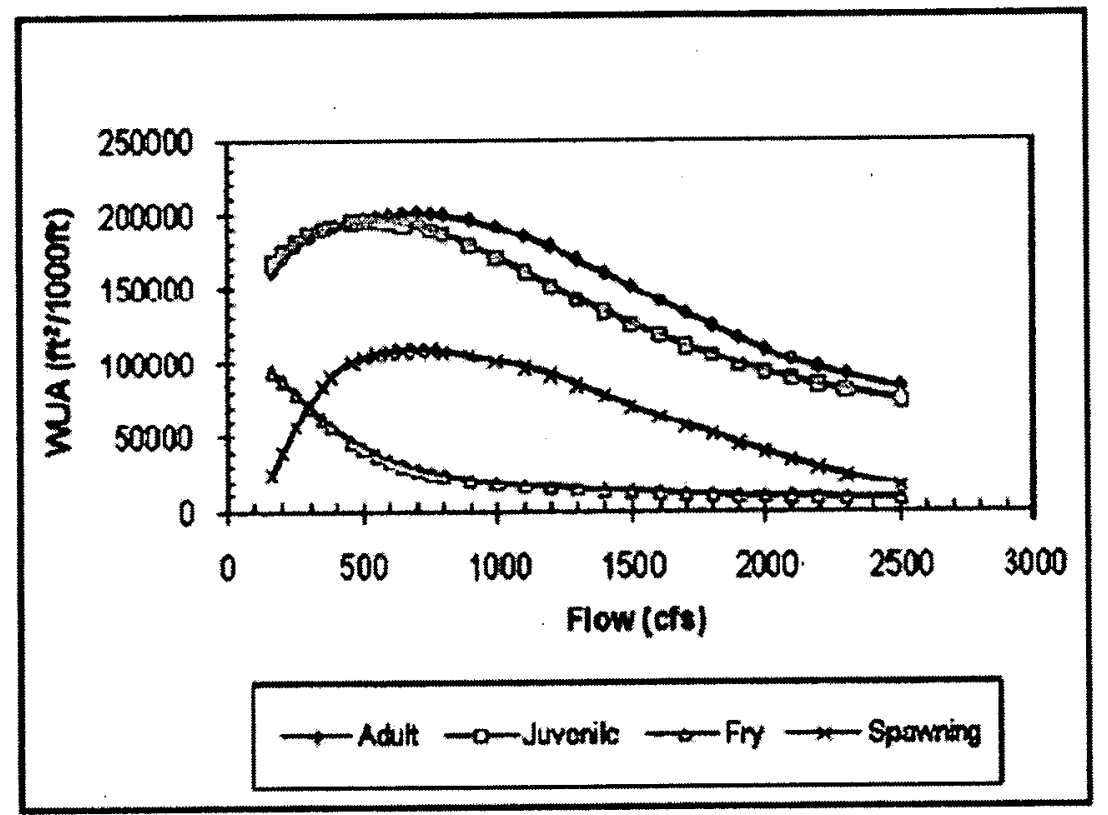

\section{Figure 11. Example WUA: Flow Curves for the Four Lifestages of Redband Trout ${ }^{128}$}

As Figure 11 demonstrates, it is not always the highest possible flow that results in the most suitable habitat. Ultimately, the quantity of water claimed is that amount that corresponds to the highest WUA for the highest priority lifestage present in the study area, subject to limitations imposed by the hydrology of the stream. ${ }^{129}$

$126 I d$. at 9 .

127 Id.

128 In re Klamath River, Aff. D. Reiser, supra note 35, at VII-5.

129 Id. at VII-59; Big Horn, Special Master Report, supra note 29, at 242. Investigators in Anderson took a different tact. There, rather than determine which lifestage had the highest priority, investigators "determine[d] the lifestage at which habitat was limiting." BARBER ET AL., supra note 28, at V. By "limiting," investigators were referring to the lifestage that required the most habitat, thereby guaranteeing sufficient habitat for all other lifestages. Id. at 82 . From this assumption, investigators found that "adult habitat was limiting at all flows for both brown trout and rainbow trout." Id. at V. Further, rather than establishing a flow for each month that maximized stream habitat for adult trout, investigators in Anderson argued that "[s]ince adult habitat is limited for both species during the month of August, a minimum flow of 27.7 CFS for each month of the year would provide enough habitat to maintain present population levels." Id. at 103. In this 


\section{Capping the Claims: Marrying the Hydraulics and Habitat Suitability to the Hydrology}

Once the IFIM/PHABSIM methodology is completed in a given stream reach the results are compared to "the hydrological regime of [the stream] system."130 IFIM/PHABSIM makes use of hydraulic modeling techniques, which are used to assess the "[physical] characteristics of stream channels-depth, ... velocity, and suspended load," for a given streamflow. ${ }^{131}$ The overall goal is to find the theoretical flow that maximizes habitat, regardless of whether or not that flow would realistically occur within the stream system. ${ }^{132}$ In contrast, hydrology is "the determination of the amount and/or flow rate of water that will be found at a given location and at a given time,"133 and "describes the general timing and magnitude of flows that occur within the system." 134 The hydraulic analysis and hydrologic analysis can sometimes be in tension because the hydraulic characteristic that maximizes instream habitat may require flows "that never occurred [in the stream], or that occur[ so infrequently that it would not be biologically meaningful." 135

This difference was a matter of considerable concern for the Special Master in the Big Horn adjudication, who at one point asked the federal fisheries expert "what is the value of your study if the state of nature puts things so that fish can live and have survived these centuries ...

case, the term "limiting" refers to the month that requires the lowest quantity of water to maintain optimum habitat. See id. at 96-97. In recommending this quantity of water, investigators assumed that since the trout population was currently surviving with the amount of habitat during the month of August, "27.7 CFS for each month of the year would provide enough habitat to maintain present population levels." Id. at 103. The only exception made was for the months of March and April, where investigators recommended a water right for the median monthly flow "to ensure adequate channel cleaning." Id. The investigator's recommendations are not preferable to the contemporary method for several reasons. First, a higher flow to maintain adult habitat may be detrimental to higherpriority life stages. For example, Figure 11 demonstrates that although the WUA for adult redband trout continues to increase up to flows around $800 \mathrm{cfs}$., WUA for the fry lifestage decreases as flow increases. See supra Figure 11. Therefore, maximizing the flow for adult fish actually harms the fry. As a result, just because more flow theoretically provides more habitat does not necessarily make more water advantageous. Furthermore, just because current fish populations are maintained with an August flow of 27.7 CFS does not necessarily mean that fish populations could be maintained at 27.7 CFS year-round.

130 In re Klamath River, Aff. D. Reiser, supra note 35, at VII-56.

131 Luna B. LeOPold \& THOMAS MADdoCK, JR., UNited States Geological SuRVEy Professional Paper No. 252: The Hydraulic Geometry of Stream ChanNels and Some Physiographic ImPlications 1 (1953); see also, Clayton T. Crowe ET AL., ENGINEERING FLUID MECHICS 12 (9th ed. 2009) (defining the difference between hyraulics and hydrology).

132 See LEOPOLD \& MADDOCK, supra note 131; In re Klamath River, Aff. D. Reiser, supra note 35 , at VII-58.

133 WILFRIED BRUTSAERT, HYDROLOGY: AN INTRODUCTION 2 (2005).

134 In re Klamath River, Aff. D. Reiser, supra note 35, at VII-57.

135 Id. at VII-58. 
with low[er] flows?"136 By way of example, on one stream at issue the Special Master asked, "[h] ow can we settle for 254 feet in January when nature only gives you 203 feet every ten years?"137 To address concerns like these, investigators today marry the stream's hydraulics with its hydrology by capping claims-on a month-by-month basis-at some level based upon the hydrology of the stream. ${ }^{138}$ For example, investigators in the Klamath adjudication determined that "the natural monthly median exceedance flow estimates ... were a reasonable upper limit on the Physical Habitat Claims." 139 They selected this upper limit based upon their conclusion that the median exceedance "represented a conservative upper limit on the Physical Habitat Claims that would nonetheless provide the amount of water necessary, and no more, for a healthy and productive habitat for the target fish species." 140

\section{E. Tying it Together: The Four Steps Applied}

The analysis explained in Part III(A)-(D) is conducted for each lifestage of each species on a reach-by-reach basis. ${ }^{141}$ The result is a matrix of possible monthly flows, each corresponding to the quantity necessary to provide healthy and productive habitat for each lifestage of the species present in the stream reach. However, only one flow is claimed for each month in each reach. Therefore, the ultimate quantity claimed is the amount of water that maximizes the available habitat for the highest priority lifestage/species, up to a predetermined limit based upon the hydrology of the stream.

Figure 12 is useful to demonstrate how the results of the IFIM/PHABSIM are often depicted. ${ }^{142}$ In this hypothetical reach there are two species: redband trout and chinook salmon. The highest-priority species and lifestage is adult redband trout during the months of January and February; spawning redband trout during March, April, May, and June; spawning chinook salmon during July, August, and September; and rearing juvenile redband trout during October,

136 Big Horn, Test. D. Vogel (Part II), supra note 29, at 6503-04; see also id. at 6411-12, 6415-18.

137 Id. at 6503.

138 In re Klamath River, Aff. D. Reiser, supra note 35, at VII-58; see also Big Horn, Test. D. Vogel (Part II), supra note 29, at 6503-06; BARBER ET AL., supra note 28, at 83.

139 In re Klamath River, Aff. D. Reiser, supra note 35, at VII-58. The monthly median exceedance flow, also known as the $50 \%$ exceedance flow, corresponds to the "flow that for a given stream and month that would be exceeded half of the time based on hydrological records." Id. at VIII-6. Importantly, although investigators identified the monthly median exceedance flow as the appropriate cap for the Klamath River system, the cap ultimately must be the flow that "ensures connection between the hydrology ... and the IFIM /PHABSIM based flow values," by being "a conservative determination of the threshold needs [to] provide a healthy and productive habitat." Id.

140 Id. at VII-58.

141 See supra Section III(A)-(D).

142 See infra Figure 12. 
November, and December. ${ }^{14}$ In Figure 11, the flows that correspond to the maximum WUA for adult, spawning, and juvenile redband trout is $700 \mathrm{cfs}, 175 \mathrm{cfs}$ and $525 \mathrm{cfs}$, respectively. ${ }^{144}$ Referring back to Figure 12 , during the month of January the highest priority lifestage/species is adult redband trout, which require $700 \mathrm{cfs}$ for a maximum WUA in this particular reach. ${ }^{145}$ The mean flow (the predetermined hydrological cap) duxing January is $1,025 \mathrm{cfs}^{146}$ and so the ultimate quantity claimed is 700 cfs.147 Similarly, in the month of July the highest priority lifestage/species is spawning chinook salmon, which require $200 \mathrm{cfs}$ for a maximum WUA in this particular reach. ${ }^{48}$ However, the mean flow in July for this stream reach is only $165 \mathrm{cfs}, 149$ Accordingly, although more water is necessary to maximize the WUA for spawning salmon the quantity ultimately clamed in this reach during the month of July is the mean monthly flow of 165 cfs. ${ }^{100}$ That trend continues through December, whereupon the mean monthly flow-780 cfs-once again exceeds the flow necessary to maximize the WUA for juvenile redband. trout (525 cfs), ${ }^{151}$ which is the highest priority lifestage/species in the reach during that month. 152

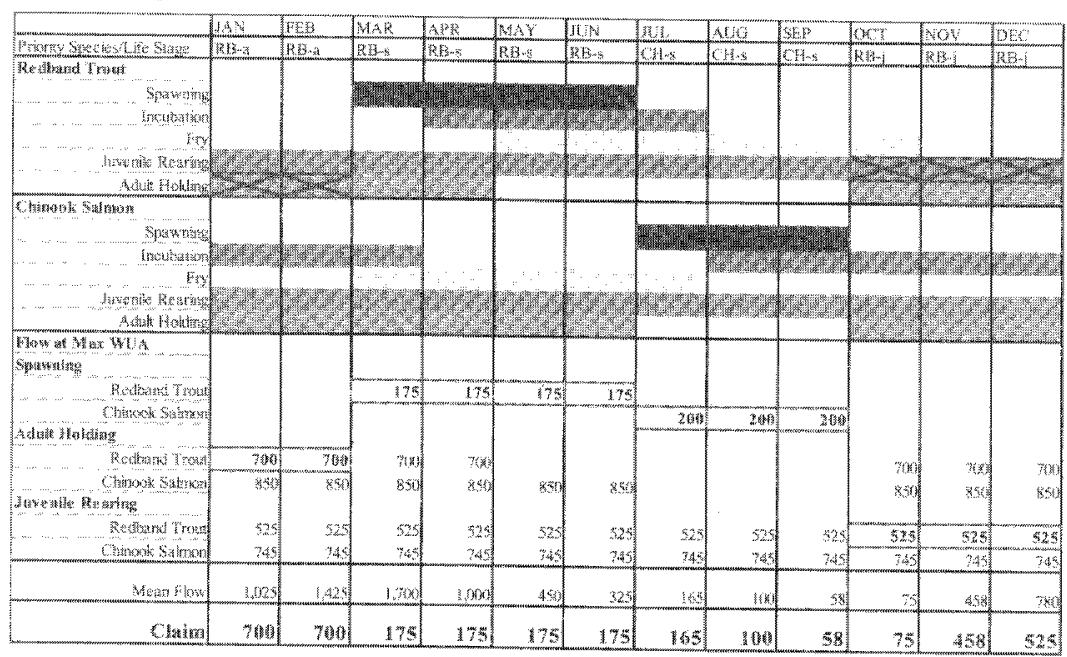

Figure 12. Example Results for a Hypothetical Stream Reach ${ }^{15}$

Lis See infro Figure 12, col. 2 k col. 3.

14. Note that a sepatete WUA flow curve for chinook salmon resuled in different fow necessury to maximize the WUA in the reach for that species. See supro Figure 11.

145 See infra Figure 12 , tow 8/col. 2 \& row $20 / \mathrm{col} .2$.

I46 See infra Figure 12 , wow $25 / 601.2$.

147 See infra Figure 12 , now $26 \mathrm{col} .2$.

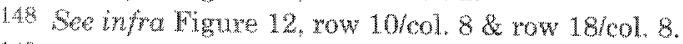

149 See infra Figues 2 , row $25 \mathrm{kol} .8$.

1 bo See infro Higure 12, wow 26/col. 8 .

151 see infro fapure 12 , row $23 / \mathrm{col}, 13 \mathrm{\alpha}$ row $25 / \mathrm{col} .13$.

158 See infra Figue 12 , row $2 \mathrm{col} .13$.

168 in Wigre 12, the abbreviations "CH" and "RB" refer to differing species and stand for chinook salmon and redband trout, respectively. The subseripts $a, s_{3}$ and $j$ reter to 
This analysis is conducted for each stream reach where a water right is claimed throughout the basin. The ultimate result is a set of claims-one for each claim reach-for quantities of water that change each month and correspond to the amount of water estimated to be necessary to maximize the available habitat for the highest priority lifestage/species present in the reach, up to the predetermined hydrologic cap. ${ }^{154}$

\section{CONCLUSION}

The people indigenous to North America have long relied upon the waterways of their homelands for their physical, spiritual, and cultural subsistence. In particular, fish and other aquatic species play a central role in the lives of many indigenous communities, particularly in the Northwestern part of what is today the United States of America. The laws of the United States recognize that where tribes have reserved the continued right to engage in their traditional subsistence practices, they likewise reserved appurtenant water rights necessary to support those important traditional activities. 155

Unlike the PIA quantification standard that was adopted by the Supreme Court for reserved irrigation water rights, no quantification standard has been universally accepted for reserved instream water rights to support fish. Although a number of standards have been suggested over time, contemporary courts have zeroed in on the "healthy and productive habitat" standard. ${ }^{156}$ This standard seeks to claim the amount of water necessary to ensure that target aquatic species continue "to exist in all life cycles in a stable and sound state." 157 Although this standard has not been adopted by the Supreme Court, and therefore continues to be controverted, it seems to be the standard that to date best approximates the mutual intent of both the federal and tribal leaders that negotiated and executed the treaties and agreements of the nineteenth century. ${ }^{158}$

Evolving over time, the contemporary methodology for determining the quantity of instream water necessary to provide a healthy and productive habitat for aquatic species is the IFIM/PHABSIM methodology. ${ }^{159}$ That method proceeds in four broad steps: "(1) study

differing lifestages and stand for "adult," "spawning," and "juvenile," respectively. All quantities are in cubic feet per second. Please note, Figure 12 is for demonstrative purposes only. It has no physical or biological basis and does not reflect an actual stream reach.

154 See, e.g., In re Klamath River, Aff. D. Reiser, supra note 35, at X-3.

155 Walton I, 647 F.2d 42, 48 (9th Cir. 1981); Adair, 723 F.2d 1394, 1408 (9th Cir. 1984); Anderson, 736 F.2d 1358, 1365 (9th Cir. 1984).

156 In re Klamath River, Aff. D. Reiser, supra note 35 , at $\mathrm{I}-11$ to -12 ; see also In re CSRBA, Aff. D. Reiser, supra note 37, at 3.

157 In re Klamath River, Aff. D. Reiser, supra note 35, at I-17.

158 See supra notes 9-11 and accompanying text.

159 Hedden-Nicely, supra note 4, at 243-44. 
site selection [and other preliminary matters], (2) field data collection, (3) development of suitability criteria, and (4) hydraulic simulation and habitat prediction." 160 In the end, the methodology seeks to estimate the monthly flow in each claimed stream reach that corresponds to the highest amount of habitat for the highest-priority lifestage present in the study area, subject to limitations imposed by the hydrology of the stream. ${ }^{161}$

As with all models of natural processes, the IFIM/PHABSIM methodology should be used with caution and with a strong understanding of the method's limitations. ${ }^{162}$ However, if used as part of a suite of other technical and legal approaches ${ }^{163}$ the IFIM/PHABSIM methodology is a robust tool to estimate the amount of water necessary to protect reservation streams. 164

Given the subject matter of this Article, it has been a technical affair. However, as we wade through these complex and technical issues, it is important that we always circle back to the ultimate goal of this effort: to protect our animal relatives that cannot always protect themselves and ensure that some sliver of the tribes' traditional culture

160 Acquavella, Aff. D. Simmons, supra note 28, at 4 .

161 See supra Section III(E).

162 In particular, the IFIM/PHABSIM method focuses solely on instream flows; it is not designed to estimate other stream processes that are important to the maintenance of fish habitat. For example, the method does not estimate flows to maintain the riparian corridor. See In re Klamath River, Aff. D. Reiser, supra note 35, at II-1. Although beyond the reach of fish, a stream's riparian area is critical to fish habitat because it provides, among other things,

(i) shade that serves to keep water temperatures cool; (ii) a supply of wood to the stream that provides shelter to fish and habitat for fish supporting organisms; (iii) a source of nutrients to the stream in the form of leaf fall; and (iv) a source of food organisms for fish resulting from insects dropping into the water from the vegetation. These [riparian maintenance] flows also help in part to maintain the channel structure, flush and transport sediments, and create new habitat structures within the channel.

Id. Likewise, the method can sometimes ignore that certain species of fish require unique flows during certain periods of the year to aid with migration, spawning, and other important biological processes. See, e.g., State Dep't of Ecology v. Acquavella, No. 77-2-01484-5, at 6 (Wash. Super. Ct. Dec. 22, 1994). Perhaps most critical, the method assumes that stream velocity, depth, and substrate remain constant through time and is based solely on analysis of static observations of those parameters. However, those parameters are constantly subject to change, particularly in an era of climate change. See Dylan R. Hedden-Nicely \& Lucius K. Caldwell, Indigenous Rights and Climate Change: The Influence of Climate Change on the Quantification of Reserved.Instream Water Rights for American Indian Tribes, 2020 UTAH L. REV. (Forthcoming Spring 2020).

163 Hedden-Nicely \& Caldwell, supra note 162; In re Klamath River, Aff. D. Reiser, supra note 35 , at II-1.

164 See Dudley W. Reiser \& Phillip J. Hilgert, A Practitioner's Perspective on the Continuing Technical Merits of PHABSIM, 43 FTSHERIES 278, 281-82 (2018); C. Stalnaker et al., Don't Throw Out the Baby (PHABSIM) with the Bathwater: Bringing Scientific Credibiltiy to Use of Hydraulic Habitat Models, Specifically PHABSIM, 42 FISHERIES 510 , 515 (2017). 
be maintained. Indeed, this was the promise that was made time and time again by the United States as it treatied with the tribes of the United States. ${ }^{165}$ Undoubtedly, the tribal people that signed those treaties had our generation in mind. Now, it is up to us to continue that good work and preserve these important traditions so that our children's children will be able to teach their children to hunt and fish in the same way as their ancestors.

165 See, e.g., Herrera v. Wyoming, No. $17-532$ (U.S. May 20, 2019); Wash. State Dep't of Licensing v. Cougar Den, Inc., No. 16-1498 (U.S. March 19, 2019); Idaho v. United States, 533 U.S. 262, 267-68 (2001); Passenger Fishing Vessel, 443 U.S. 658, 664 (1979); Kimball v. Callahan, 493 F.2d 564, 566 (9th Cir. 1974); Menominee Tribe of Indians v. United States, 391 U.S. 404, $404-05$ (1968); Winters, 207 U.S. 564, 576 (1908); United States v. Winans, 198 U.S. 371, 377-78 (1905); Adair, 723 F.2d 1394, 1408 (9th Cir. 1984); Walton I, 647 F.2d 42, 45 (9th Cir. 1981); United States v. Idaho, 95 F. Supp. 2d 1094, 1100, 1108 (D. Idaho 1998); United States v. Washington, 384 F. Supp. 312, 331 (W.D. Wash. 1974); Klamath \& Modoc Tribes v. Maison, 139 F. Supp. 634, 635 (D. Or. 1956); State v. Tinno, 497 P.2d 1386, 1389 (Idaho 1972). 